Coal Combustion and Conversion Technology 
Other titles published in this series

Hydrogen and Energy Charles A. McAuliffe

Fuel Cells Angus McDougall 


\title{
Coal Combustion and Conversion Technology
}

\author{
D. Merrick \\ National Coal Board \\ Coal Research Establishment \\ Stoke Orchard \\ Cheltenham
}

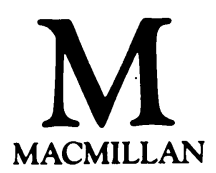


(C) D. Merrick 1984

Softcover reprint of the hardcover 1st edition 1984

All rights reserved. No part of this publication may

be reproduced or transmitted, in any form or by

any means, without permission.

First published 1984 by

Higher and Further Education Division

MACMILLAN PUBLISHERS LTD

London and Basingstoke

Companies and representatives

throughout the world

ISBN 978-1-349-06199-0

ISBN 978-1-349-06197-6 (eBook)

DOI 10.1007/978-1-349-06197-6 


\section{CONTENTS}

Preface vii

1 Introduction 1

1.1 Origin and nature of coal 1

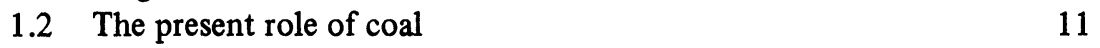

$\begin{array}{lll}1.3 & \text { Future prospects } & 19\end{array}$

2 History of Coal Combustion and Conversion Technology 25

$\begin{array}{ll}2.1 \text { Fluidised bed combustion } & 25\end{array}$

$\begin{array}{lll}2.2 \text { Gasification } & 28\end{array}$

$\begin{array}{lll}2.3 & \text { Liquefaction } & 31\end{array}$

3 Fluidised Bed Combustion $\quad 38$

3.1 Fluidisation $\quad 39$

3.2 Chemical reactions $\quad 42$

3.3 Atmospheric pressure FBC boilers 47

3.4 Atmospheric pressure FBC furnaces $\quad 59$

$\begin{array}{lll}3.5 & \text { Fast fluidised bed systems } & 62\end{array}$

$\begin{array}{lll}3.6 & \text { Pressurised fluidised bed combustion } & 67\end{array}$

$\begin{array}{lll}3.7 & \text { Power generation applications } & 71\end{array}$

$\begin{array}{ll}3.8 \text { Industrial applications } & 80\end{array}$

4 Gasification $\quad 101$

$\begin{array}{ll}4.1 \text { Chemical reactions } & 101\end{array}$

$\begin{array}{lll}4.2 & \text { Gasifier designs } & 108\end{array}$

$\begin{array}{lll}4.3 & \text { Gas processing } & 124\end{array}$

$\begin{array}{lll}4.4 & \text { Synthesis technologies } & 142\end{array}$

4.5 Substitute natural gas and industrial gases 152

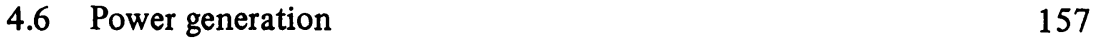

$\begin{array}{ll}4.7 & \text { Liquid fuels and chemicals } \\ \end{array}$

5 Liquefaction $\quad 168$

$\begin{array}{lll}5.1 & \text { Chemistry of liquid fuels } & 168\end{array}$

$\begin{array}{ll}5.2 \text { Classification of processes } & 171\end{array}$

$\begin{array}{lll}5.3 \text { Pyrolysis } & 174\end{array}$

$\begin{array}{llr}5.4 \text { Hydropyrolysis } & 182\end{array}$

$\begin{array}{lll}5.5 & \text { Solvent extraction } & 186\end{array}$

$\begin{array}{ll}5.6 \text { Hydrogenation } & 192\end{array}$ 
vi

$\begin{array}{lll}5.7 & \text { Solids separation } & 203\end{array}$

$\begin{array}{lll}5.8 & \text { Process configurations } & 208\end{array}$

$\begin{array}{ll}5.9 & \text { Refining coal-derived liquids } \\ 5.10 & 214\end{array}$

$\begin{array}{ll}5.10 \text { Production applications and properties } & 222\end{array}$

$\begin{array}{ll}5.11 \text { Comparison of direct and indirect liquefaction } & 228\end{array}$

6 Other Technologies 231

6.1 Remote extraction 231

$\begin{array}{lll}6.2 & \text { Coal preparation } & 237\end{array}$

$\begin{array}{lll}6.3 & \text { Transport } & 239\end{array}$

$\begin{array}{ll}6.4 \text { Handling } & 243\end{array}$

$\begin{array}{lll}6.5 & \text { Domestic market } & 248\end{array}$

$\begin{array}{lll}6.6 & \text { Industrial market } & 257\end{array}$

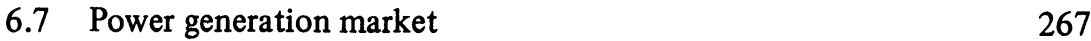

$\begin{array}{lll}6.8 & \text { Coke manufacture } & 280\end{array}$

$\begin{array}{ll}6.9 \text { Combined processes } & 287\end{array}$

7 Environment $\quad 293$

$\begin{array}{lll}7.1 & \text { Particulate matter } & 296\end{array}$

$\begin{array}{lll}7.2 & \text { Sulphur } & 299\end{array}$

$\begin{array}{lll}7.3 & \text { Nitrogen oxides } & 306\end{array}$

$\begin{array}{ll}7.4 \text { Carbon dioxide } & 310\end{array}$

$\begin{array}{lll}7.5 & \text { Trace species } & 314\end{array}$

$\begin{array}{ll}7.6 & \text { Liquid effluents } \\ 7.7 & 321\end{array}$

$\begin{array}{lll}7.7 & \text { Solid residues } & 324\end{array}$

$\begin{array}{lll}7.8 & \text { Other environmental impacts } & 328\end{array}$

8 Economics $\quad 331$

$\begin{array}{lll}\text { 8.1 Design considerations } & 331\end{array}$

8.2 Economic assessment methods $\quad 335$

8.3 Energy models 349

8.4 Economics of coal conversion processes $\quad 352$

$\begin{array}{lll}8.5 & \text { Economics for final consumers } & 364\end{array}$

Appendix 1: Developments in coal utilisation technology 382

Appendix 2: Economic data for selected processes 390

Appendix 3: Abbreviations 393

Appendix 4: Units $\quad 394$

$\begin{array}{ll}\text { Bibliography } & 396\end{array}$

$\begin{array}{lr}\text { Index } & 398\end{array}$ 


\section{PREFACE}

By the middle of the twentieth century, coal, although still the dominant world energy source, had come to be regarded as the product of a traditional industry nearing the end of its useful life-cycle. The prospect of cheap and plentiful energy supplies from oil and nuclear power promised to make the early decline of the coal industry inevitable. During the 1970s, however, attitudes changed dramatically. Oil price increases and doubts about the planned expansion of nuclear power led to a widespread recognition that coal had an important and long-term contribution to make. In parallel, there was a revival of interest in coal technology, particularly in methods of using coal with greater efficiency, environmental acceptability and versatility than previously.

This book is intended as a guide to coal utilisation technology, with the emphasis on new systems under development for the future, especially in the short and medium term. The traditional coal utilisation technologies are also discussed in the context of the future use of coal.

The book has been written for students, engineers, planners and policy makers with an interest in coal, rather than the specialist research worker. Inevitably, some scientific background is assumed, but a knowledge of coal utilisation technology is not required. Both the underlying scientific principles and engineering approaches are covered. However, recent developments in research programmes have been rapid, and no attempt is made to provide a complete catalogue of systems currently under investigation. Instead, engineering approaches are dealt with in terms of their general characteristics and classification so that the reader may be provided with a framework against which to assess specific schemes and future concepts.

The first two chapters discuss coal's position as a world energy source, and the historical background to the present technology and developments. The major technologies themselves, fluidised bed combustion, gasification and liquefaction, are considered in the next three chapters, followed by a further chapter describing other lines of technology under investigation. The last two chapters are devoted to the environmental and economic aspects of coal utilisation, respectively.

In general, SI units have been used throughout the book although, for convenience, pressures are expressed in bar and temperatures in ${ }^{\circ} \mathrm{C}$.

In writing this book, I am indebted to a large number of colleagues at the Coal Research Establishment and other parts of the National Coal Board, including the Coal Utilisation Research Laboratories, Mining Research and Develop- 
ment Establishment, the Economic Assessment Service of IEA Coal Research, Technical Information Branch and Operational Research Executive. I am extremely grateful for their help in providing information and in commenting on drafts. I would particularly like to thank those most closely involved: Mr J. Highley, Dr J. Holmes, Miss S. Lauder, Dr P. F. M. Paul and Mr. A. A. Randell.

I would also like to thank the National Coal Board for permission to publish this book. Any views implied or expressed are, of course, those of the author and not necessarily those of the National Coal Board. 